\title{
The impact of managerial political ties on corporate governance and debt financing: Evidence from Ghana
}

\author{
Tahiru Azaaviele Liedong ${ }^{\mathrm{a},{ }^{*}}$, Tazeeb Rajwani ${ }^{\mathrm{b}}$ \\ a School of Management University of Bath, Claverton Down Road, Bath, BA2 7AY, United Kingdom \\ ${ }^{\mathrm{b}}$ Essex Business School, University of Essex, Southend Campus, Elmer Approach, Southend-On-Sea, SS1 1LW, United Kingdom
}

\section{A R T I C L E I N F O}

\section{Article history:}

Available online 12 July 2017

\section{Keywords:}

Political ties

Corporate governance

Cost of debt

Mediation

Ghana

\begin{abstract}
A B S T R A C T
In this study, we draw upon insights from agency theory to examine the impact of managerial political ties on cost of debt and also to explore whether corporate governance mediates this impact. We hypothesize that political ties reduce financial reporting quality, disclosure of non-financial information and board independence, and are therefore associated with higher interest rates. We also hypothesize that the negative effect of political ties on the cost of debt will be stronger if firms borrow from privately-owned banks versus government-owned banks. Using data from Ghana, we find support for our direct and moderation hypotheses; political ties are associated with high interest rates and poor corporate governance. However, we do not find evidence of mediation. Altogether, the findings reveal the dark side of political connections and highlight the cost of political embeddedness in emerging credit markets.
\end{abstract}

() 2017 Elsevier Ltd. All rights reserved.

\section{Introduction}

Political strategy researchers have explored the benefits of political ties, defined as the personal and social relationships managers develop and maintain with politicians (Guo et al., 2014; Park and Luo, 2001). Indeed, over the last two decades there has been a proliferation of literature focusing on value of political ties (see Mellahi et al., 2016; Rajwani and Liedong, 2015). Particularly, there is increasing attention on the link between political ties and debt financing. The small body of research focusing on this topic unanimously shows that political ties enable firms to gain access to bank loans (e.g. Saeed et al., 2015; Yeh et al., 2013). However, it is still not clear whether these ties enable firms to get loans at lower interest rates. Although previous studies have examined the impact of political ties on the cost of debt (e.g. Bliss and Gul, 2012; Chen et al., 2014; Houston et al., 2014), the findings are far from conclusive.

Additionally, literature on the impact of corporate political activity (CPA henceforth) on firm performance in general, and on the cost of debt in particular, suffers from an under-examination of mediating mechanisms (see Guo et al., 2014; Mellahi et al., 2016). At best, researchers conjecture mediation to explain their empirical findings. While conjecturing is a good step towards theorization, the lack of empirical verification curtails a deeper understanding of the means or intermediate outcomes through which political ties are translated into value-adding or value-eroding outcomes (Rajwani and Liedong, 2015).

Related to the above, majority of political strategy studies focus on developed markets and a few emerging markets in Asia (e.g. Johnson and Mitton, 2003; Leuz and Oberholzer-Gee, 2006). Thus, there have been calls to extend strategy research to

\footnotetext{
* Corresponding author.

E-mail addresses: T.A.liedong@bath.ac.uk (T.A. Liedong), tazeeb.rajwani@essex.ac.uk (T. Rajwani).
} 
Africa (Mellahi and Mol, 2015; Wright et al., 2005) where important management issues remained underexplored (George et al., 2016). In emerging and developing countries, especially in Africa, access to finance and cost of debt are major impediments to firms (Aryeetey, 1998; Beck et al., 2006). Similarly, corporate governance is very poor in these countries (Young et al., 2008). Could poor governance be a mechanism affecting debt financing in emerging countries? This question is important but has not been adequately addressed, especially in the African context. Moreover, the existing political ties studies in emerging countries draw more on resource based view or dependency theory (Li and Zhang, 2007; Shirodkar and Mohr, 2015), institutional theory (Nell et al., 2015; White et al., 2015) and social network theory (Acquaah, 2007; Peng and Lu1, 2000). Though these theories help to explain political activity in emerging countries, they neglect or are perhaps inappropriate to investigate principal-agent relationships and governance dynamics in politically connected firms. Political activity has governance implications which underpin firms' performance (Hadani and Schuler, 2013). In emerging countries where institutional development is fragile (Acquaah, 2007; Xin and Pearce, 1996), these implications might even be more serious and deserve adequate research attention. Therefore, agency theory is useful for explaining governance practices and organizational behaviours (Eisenhardt, 1989) that mediate the link between political activity and firm-level contractual outcomes.

In this study, we attempt to address the above research gaps using the agency perspective to examine the relationship and mediating mechanisms between political ties and the cost of debt. We propose that the quality of corporate governance in politically connected firms mediates the interest rates these firms are charged when they borrow from banks. Precisely, we argue that politically connected firms have stronger motivations to misreport their financial performance in order to conceal any inappropriate economic appropriation (Guedhami et al., 2014). Thus, the quality of financial reports produced by connected firms is low (Chaney et al., 2011). Also, fraudulent practices in these firms are detected late and the penalties for misbehaviour are usually lenient (Correia, 2014; Yu and Yu, 2011). We contend that leniency in dealing with connected firms will particularly be common in emerging countries where the formal institutions for ensuring compliance are weak or fraught with political interference. Therefore, banks will penalize connected firms with high interest rates to compensate for information asymmetry and risk.

Additionally, we argue that connected firms in emerging countries would want to reduce their visibility to institutional stakeholders in order to avoid scrutiny, especially when their political ties become volatile (Decker, 2011). This implies that the disclosure of non-financial information in these firms will be low, a situation that has negative consequences for loan financing. Further, the strong motivation to avoid scrutiny will cause politically connected firms to have fewer independent or external directors. The resultant weak monitoring and lack of external oversight will reduce creditworthiness and lead to high interest rates (e.g. Anderson et al., 2004; Bhojraj and Sengupta, 2003).

Our study contributes to CPA literature in several ways. First, it adds to the growing strategy research on the performance outcomes of political strategies and sheds more light on the implications of political ties in credit markets. It is worth noting that the effect of political ties on cost of debt has not received adequate attention, despite the importance of loan finance for firms in emerging markets (Beck and Demirguc-Kunt, 2006). Findings from the few studies that have examined this topic are mixed and inconclusive. For example, on one hand, political ties influence profitability, enhance the creditworthiness of firms and culminates in low loan rates (Houston et al., 2014). On the other hand, political ties may cause poor corporate governance, reduce firm performance, increase information asymmetry and result in high loan rates (Bliss and Gul, 2012). Our study joins this debate and attempts to clarify the impact of political ties in credit markets. Additionally, our study demonstrates how bank ownership moderates the relationship between political ties and interest rates. The findings suggest that due to the principal-agency relationship existing between politicians (principals) and government-owned banks (agents), these banks tend to overlook the agency problems inherent in connected firms. Essentially, government-owned banks are policy tools used by politicians to redistribute or allocate resources (Sapienza, 2004).

Second, this study offers a cautionary insight into the negative effect of political activity on corporate governance. In other words, it addresses the influence of political connections on corporate governance and financial behaviour (Chaney et al., 2011), and shows that there is a dark side to corporate political embeddedness (Okhmatovskiy, 2010). This contribution is very important because even though the dark side of political activity has been documented (Doh et al., 2012; Sun et al., 2016), there is still a paucity of empirical research on what the specific dark elements are, particularly with respect to corporate transparency and monitoring (Okhmatovskiy, 2010).

Finally, this study attempts to enhance our understanding of how political ties affect cost of debt. As noted previously, one of the notable shortcomings in CPA literature is the limited treatise of mediating mechanisms (Guo et al., 2014). By empirically examining the mediating role of agency in the political ties-cost of debt relationship, this study transcends a conjecture of mediation as is commonly done in existing finance and management research. Our findings show that even though political ties lead to poor governance, poor governance does not seem to mediate the impact of political ties on the cost of debt. This suggests that the size of protection or the value of insurance connected firms gain from politicians (e.g. Li and Zhang, 2007; Luo and Zhao, 2013; Xin and Pearce, 1996) causes banks to overlook the inherent information opaqueness in these firms. In sum, this study suggests that in emerging countries, connected firms' poor governance is reinforced by the unwillingness of politicians and government agencies to enforce compliance and also by the failure of business entities such as banks to penalize them (through loan rates) for their illegal and unethical behaviour.

The rest of the paper proceeds as follows. In the next sections, we review related literature and theory before developing the hypotheses. We then describe the methodology, present the results and discuss the contributions of the study. We conclude with a note on limitations and suggestions for future research. 


\section{Theoretical background and hypotheses}

Research on the impact of political ties in debt financing has yielded controversial findings. For instance, Leuz and Oberholzer-Gee (2006) found that local political patronage offsets the benefits of global financing and enables connected firms in Indonesia to access financing at lower costs. This finding is corroborated by Claessens et al. (2008) in Brazil, Chen et al. (2014) in Taiwan, Khwaja and Mian (2005) in Pakistan and Houston et al. (2014) in the U.S. Other studies, however, show that the effect of political ties in credit markets is negative. For instance, Bliss and Gul (2012) found that connected firms are charged high interest rates in Malaysia.

Some of the studies above have attempted to theoretically explain the mechanisms underlying the impact of political ties on debt financing (e.g. Bliss and Gul, 2012; Houston et al., 2014; Yeh et al., 2013). First, they argue that government ownership of banks creates an implicit requirement for loan officers and bank executives to honour the preferences of politicians (Yeh et al., 2013). Therefore, government-owned banks are captives of government officials. Acts of insubordination can be penalized with dismissal or demotion (Khwaja and Mian, 2005). Consequently, politically connected firms are treated favourably by these banks (Chen et al., 2014). Second, they highlight that weak institutions and high levels of corruption make it possible for politicians to influence lending decisions (Barth et al., 2009) and discriminate in favour of politically connected firms (Brandt and Li, 2003). Third, they suggest that banks will give preferential treatment to connected firms in order to gain an indirect access to the corridors of political and regulatory power (Houston et al., 2014). Having access to politicians, through cordial lending relationships with connected firms, could avail some economic benefits to the banks, such as winning government underwriting business (Butler et al., 2009) and contracts (Witko, 2011) or even participating in government foreign trade missions (Schuler et al., 2002). Fourth, they note that increased riskiness in politically connected firms leads to high interest rates (Bliss and Gul, 2012). The main thrust of this argument resonates with the fact that connected firms are highly leveraged (Fraser et al., 2006) and have a higher propensity to record negative equity (Bliss and Gul, 2012). Essentially, the riskiness argument is consistent with the agency and corporate governance concerns that are commonly anticipated or observed in connected firms (Gul, 2006).

Considering the paucity of empirical research on the mediating mechanisms of political connections (Guo et al., 2014; Rajwani and Liedong, 2015), and the enormous negativity about corporate governance in politically connected firms (Guedhami et al., 2014), especially in emerging countries where the dark side of CPA (Doh et al., 2012) is more likely to manifest through corruption (Lawton et al., 2013a) and rent appropriation (Sun et al., 2016), there is the need for research to empirically explore how the quality of corporate governance mediates the impact of political ties in credit markets. The need for this line of enquiry is even greater in empirically under-researched contexts such as Ghana where State institutions are weak, interest rates are very high, and corporate governance is poor (Aboagye et al., 2008; Mensah and Abor, 2014; Tsamenyi et al., 2007).

CPA research in emerging countries has mainly drawn upon resource-based and institutional theories. These theories support the unanimity that political ties help firms to secure more bank loans (e.g. Fraser et al., 2006; Johnson and Mitton, 2003; Khwaja and Mian, 2005). For instance, since political ties serve as substitutes for weak market supporting institutions in emerging countries (Xin and Pearce, 1996), institutional theory mainly portrays political ties as positive and necessary. Similarly, resource based view theory portrays political ties and political capabilities as crucial sources of competitive advantage (Lawton et al., 2013b).

However, because political ties can add or destroy value (Rajwani and Liedong, 2015), institutional and resource-based logics have limited ability to explain the negative outcomes of political activity. Political connections can help to align government policy with the preferences of interest groups, but they can also lead to agency problems (Sun et al., 2016) and poor firm performance (Hadani and Schuler, 2013). In credit markets, political ties could lead to high interest rates due to high leverage and compromised management in connected firms (Bliss and Gul, 2012). More importantly, implicit guarantees of protection from politicians (see Faccio et al., 2006) could lead to a moral hazard problem in connected firms. Therefore, agency theory is appropriate for investigating the mechanics of contractual outcomes because of its suitability for studying negative behaviours such as deception and secrecy (Eisenhardt, 1989), which could be politically-motivated.

Agency theory is particularly important for strategy research in emerging countries (Hoskisson et al., 2000; Wright et al., 2005) where uncertain environments and a general lack of managerial skills can lead to strategic decisions that may be inconsistent with widely acceptable governance practices. Formal institutions such as regulations regarding financial reporting and disclosure are either not existent or not effectively enforced (Young et al., 2008). In other words, there is little institutional support for standard corporate governance practices in emerging countries (Peng, 2004). In these countries, the rule of law is prone to political interference (Sun et al., 2016), implying that disciplinary actions against politically connected firms could be difficult to enforce. This makes governance an important yardstick for assessing creditworthiness (Bliss and Gul, 2012; Holder-Webb and Sharma, 2010).

\section{Political ties and cost of debt}

Research has shown that the impact of political connections on cost of debt varies with the level institutional development. These connections are more valuable in developed countries compared to emerging credit markets. For example, Infante and Piazza (2014) found that politically connected firms in Italy borrow at low interest rates. Similarly, Houston et al. (2014) who studied the political ties of S\&P 500 companies in the U.S found that firms with politicians on their boards are 
associated with lower cost of debt. According to Houston and colleagues, political connections reduce the average loan spread by approximately $13-20$ basis points, mainly as bankers recognize the positive influence political connections have on profitability, information access and policy risk reduction (e.g. Bradley et al., 2016; Goldman et al., 2009; Hillman et al., 1999; Hillman, 2005).

In emerging countries also, political connections are associated with profitability (Acquaah, 2007; Peng and Luo, 2000). Connections enable firms to overcome bureaucracy (Luo, 2001), exploit their policy environments and obtain key resources which help them to develop competitive capabilities (Xin and Pearce, 1996) and recognize entrepreneurial opportunities (Guo et al., 2014). Moreover, these connections allow firms to influence resource allocation and gain institutional support (Li and Zhou, 2010). Essentially, the prevalence of weak market supporting institutions in emerging countries suggests that social relationships, including political ties, are important for economic exchange (Peng and Luo, 2000; Sheng et al., 2011).

Despite the advantage of political ties in emerging countries, banks may still perceive connected firms to be risky. As noted by Park and Luo (2001), cultivating and sustaining political ties can be costly, particularly when firms have to reciprocate by supporting government's social and economic goals (Luo, 2001, 2004) or by giving gifts to politicians (Peng and Luo, 2000). Political ties can also stifle organizational agility in dynamic environments (Sun et al., 2010) and cause firms to diverge from shareholders' interests (Okhmatovskiy, 2010) through the "grabbing hand" of politicians (Shleifer and Vishny, 1998). Moreover, the absence of effective institutional checks and balances in emerging countries affords connected firms the opportunity to default on loans and indulge in morally hazardous behaviour because they are protected by politicians.

Consequently, banks are conservative or negative about the creditworthiness of connected firms. For example, Bliss and Gul (2012) found that due to their high inherent risk (Johnson and Mitton, 2003; Gul, 2006), connected firms are charged high interest rates in Malaysia. Generally in emerging countries, corporate governance is poor (Young et al., 2008) and the dark side of political connections is more likely to manifest through agency problems and corruption (Effiezal et al., 2011; Lawton et al., 2013a; Sun et al., 2016). Therefore, we propose that banks will charge high interest rates to compensate for the high agency costs in connected firms.

H1. Managerial political ties are positively related to the cost of debt in emerging countries.

\section{Moderation of bank ownership}

The important role of government-owned banks in giving preferential treatment to politically connected firms has been documented in the literature (e.g. Chen et al., 2014). In most countries, governments own or have controlling stakes in banks (La Porta et al., 2002), and in these banks, it is politicians who determine the constitution of the Boards and top management teams. As a result, bank executives (i.e. agents) are expected to perform their duties in accordance with the preferences of politicians (i.e. principals), which makes them less sensitive to the riskiness of connected firms. Managers could be transferred, demoted or removed if they do not comply with political directives (Khwaja and Mian, 2005). Therefore, governmentowned banks are vessels used by politicians to achieve personal ends (Onder and Ozyildirim, 2011). For instance, in election years, these banks increase their lending relative to private banks (Dinc, 2005), with most of the loans going to firms located in the areas where the incumbent political party has strong support (Sapienza, 2004).

Privately-owned banks, however, are not expected to give undue preferential treatment to politically connected firms. In principle, the principal-agent relationship existing between politicians and government-owned banks is not the same for privately-owned banks. As their management is expected to be independent of political interference, privately-owned banks are less likely to pursue politically-motivated lending. In fact, because of the costs of political embeddedness (Okhmatovskiy, 2010; Siegel, 2007; Sun et al., 2012), privately-owned banks might penalize politically connected firms with high interest rates. In emerging countries such as Ghana, privately-owned banks lack adequate political support to pursue or take recovery actions against defaulting connected firms. Hence, they are likely to charge high interest rates for the high risk. We therefore hypothesize the following:

H2a. The positive relationship between political ties and the cost of debt is weakened when firms borrow from governmentowned banks.

H2b. The positive relationship between political ties and the cost of debt is strengthened when firms borrow from privatelyowned banks.

The mediating role of financial reporting quality

Political ties can lead to high interest rates by promoting and supporting poor financial reporting cultures in firms. In fact, prior studies have considered low quality financial information as an outcome associated with political connections (Chaney et al., 2011), mainly as connected firms may report little information to cover up operational inefficiencies or appropriation activities that stem from political cronyism (Guedhami et al., 2014; Gul, 2006). Politicians could also use overinflated or fictitious contracts to channel corruption proceeds into the accounts of connected firms. As these firms "derive gains from their connections over and above the payments they make" (Wang et al., 2017: 146), they will be less inclined to accurately report their earnings. Moreover, firms rarely report political spending in their financial statements (Aggarwal et al., 2012; 
Hadani and Schuler, 2013), which gives managers an incentive to conceal or distort financial information in order to avoid outsider or shareholder interference (Leuz et al., 2003).

Additionally, political ties enable firms to avoid the discipline of corporate governance rules and regulations (Luo, 2001; Sun et al., 2016). Connected firms are known to report low quality financial information (Chaney et al., 2011). They may also indulge in fraudulent behaviours which are usually detected late (Yu and Yu, 2011). As most courts in emerging countries are rarely independent of political interference, fraudulent connected firms are less likely to be penalized. They also have higher chances of favourable appeals against court decisions (Firth et al., 2011). Even in advanced countries, connected firms face lower penalties when they are prosecuted (Correia, 2014). These findings suggest that connected firms are protected by politicians (Chaney et al., 2011), which creates a moral hazard problem whereby these firms are careless about their financial behaviour. In Ghana and other African countries where corporate governance is still developing (Abor and Fiador, 2013) and political systems are still consolidating (Luiz and Stewart, 2014), there is sufficient expectation that political ties will lead to poor financial reporting quality.

Moreover, there are costs associated with political ties (Park and Luo, 2001; Peng and Luo, 2000). For instance, politically connected firms may be required by politicians to fund public and social programs (Luo, 2001, 2004) or even contribute to political campaigns. Managers may exclude these expenditures from their financial reports, which creates agency problems and conceals the true state of the firms' financial health. Poor financial reporting can affect the ability to raise loan capital (Chen et al., 2011). Firms with poor accounting information have high agency and information risk (Lin et al., 2014), and are either denied credit, charged high interest rates or made to pledge huge collateral (Bharath et al., 2008). Therefore, we propose that:

H3. Financial reporting quality mediates the positive relationship between political ties and cost of debt in emerging countries.

\section{The mediating role of non-financial disclosure}

In the context of emerging countries, we assert that political ties do not promote the disclosure of non-financial information. Insights from the literature suggest that politically connected firms are likely to be invisible or less transparent, especially when they enjoy substantial benefits of dubious legality (Chaney et al., 2011; Leuz and Oberholzer-Gee, 2006). Nonfinancial reports will increase their visibility, and could cause shareholders and other institutional actors to question not only the issues captured in the disclosures but also to peruse their financial reports. In effect, politically connected firms might view non-mandatory disclosures as unwanted audit invitations to outsiders. Therefore, political ties will lead to an opaque disclosure culture, mainly to conceal from external stakeholders any questionable future revenue streams such as solesourced government contracts, illegal licenses, cheap privatized acquisitions or even liabilities arising from political risks.

The resultant information asymmetry will adversely affect loan pricing. Banks and other investors usually look up corporate information prior to making loan decisions (Bharath et al., 2008). In very risky environments such as Ghana, past financial information may not be informative of future cash flows, thus banks use non-financial and governance disclosures to support decision making (Bhojraj and Sengupta, 2003). We propose that political connected firms discourage these explicit disclosures in order to reduce their visibility, which subsequently leads to high loan rates. We propose that:

H4. Non-financial disclosure mediates the positive relationship between political ties and cost of debt in emerging countries.

The mediating role of board independence

Politically connected managers and CEOs will have little incentive to ensure that their actions and those of their firms are monitored by external and professional board members, mainly as effective monitoring could obstruct politically-motivated appropriation or spending. At best, connected firms may prefer to appoint internal directors who will serve as allies to politically connected CEOs and help protect political interests, rather than shareholders' interests (Yeh et al., 2013). These internal (executive) directors are likely to overlook executives' behaviour, which will culminate in unchecked CEO power. In this respect, political ties will cause low board independence in firms.

Finance and management research shows that board independence is associated with low spreads and bond yields (Bhojraj and Sengupta, 2003; Lin et al., 2014), mainly as non-executive directors can make more efficient corporate decisions (Rosenstein and Wyatt, 1990), control CEO compensation (Boyd, 1994), easily fire an under-performing CEO (Weisback, 1988) and reduce corporate risk-taking (Bargeron et al., 2010). Also, the likelihood of financial statement fraud is lower when there are non-executive directors on corporate boards (Beasley, 1996). Their presence leads to stricter monitoring and lower cost of debt (Francis et al., 2012). In emerging countries, evidence shows that board independence reduces agency costs (Rashid, 2015) and influences access to finance (Abor, 2007). This is because lenders use board independence as a measure of borrower reliability (Holder-Webb and Sharma, 2010). We propose that the lack of board independence in politically connected firms leads to high interest rates.

H5. Board independence mediates the positive relationship between political ties and cost of debt in emerging countries. 


\section{Research methodology}

\section{Context \& motivation}

Investigating the mediating mechanisms of debt financing in Ghana is important for several reasons. First, access to finance is a major hindrance to private sector development in emerging countries (Beck and Demirguc-Kunt, 2006). In Ghana particularly, credit is rationed (Robson et al., 2013) and firms are charged high interest rates. By focusing on the cost of debt, we explore a phenomenon which has real significance for firms operating in a bank-based economic system. Second, Ghana has one of the highest interest rate regimes in the world (Aboagye et al., 2008). According to data from the central bank, Ghana's monetary policy and interbank lending rates stood at $26 \%$ and $25.29 \%$ respectively as of December 2015 , which are very high even within the Africa region. Third, corporate governance in Ghana is poor (Tsamenyi et al., 2007), and this phenomenon is expected to affect the pricing of loans. Processes to ensure accountability and financial prudence are not effectively implemented (Agyeman et al., 2013; Bokpin, 2009). Moreover, the criteria for appointing board members and evaluating board performance are not institutionalized or well-defined (Simpson, 2014). Fourth, Ghana has weak market supporting institutions, which create an imperative for firms to develop and use networking relationships in economic transactions (Acquaah, 2007). Political ties are therefore prevalent in the country, but they are rarely studied. For the above reasons, Ghana provides a suitable context for examining not only the effect of political ties on cost of debt but also the mediating role of corporate governance.

\section{Sample and data collection}

Most of the firms in Ghana are privately owned. Consequently, it is difficult to obtain archival data, especially financial information (Acquaah, 2007; Amoako-Gyampah and Boye, 2001). Therefore, we used a survey which we designed and pilot tested in three stages with 20 managers in Ghana to examine the validity of the questions (Mesquita and Lazzarini, 2008). All the measures in the questionnaire were developed from theory. Important issues and general rules of thumb about ambiguous questioning, technical jargons, questionnaire layout, and length were all taken into consideration during the survey design.

Due to the lack of secondary data for management research in Ghana, most researchers use surveys. Consequently, firms are usually ladened and inundated with many questionnaires, resulting in respondent fatigue and nonchalance. We therefore found it imperative to distinguish our survey. We obtained endorsements from the Ghana Investment Promotion Centre (GIPC), the Association of Ghana Industries (AGI) and the Ghana Association of Bankers (GAB). These endorsees play important roles in promoting the private sector in Ghana, and were thus chosen to enhance the credibility of our study. For example, AGI is a business group made up of over 1200 small, medium and large scale manufacturing firms in Ghana.

The data for this study was collected from senior managers such as Chief Executive Officers (CEOs), Managing Directors (MDs) and their deputies. Following prior studies (Robson et al., 2013), we developed a sample of 300 firms from multiple sources such as the membership directory of AGI, Ghana Business Directory and Ghana Club 100. Questions in the survey made reference to the past three years as the time frame for responses (i.e. 2011, 2012, and 2013); hence all the sampled firms had operated in Ghana for at least three years prior to 2014. Due to poor postal services and lack of a well-functioning address system in Ghana, the questionnaires were delivered on-site. We collected 179 surveys from firms operating in 21 industries, resulting in a final response rate of $59.6 \%$.

\section{Validity and reliability}

Common Method Variance (CMV) is an important concern in survey research (Chang et al., 2010). We therefore used various techniques to addressed CMV. First, we created cognitive speed bumps by reverse-phrasing some of the questions in order to reduce acquiescence bias (Hinkin, 1995; Winkler et al., 1982). We did this because we suspected a high rate of acquiescence bias in Ghana due to the increased use of questionnaires and the associated respondent fatigue. Second, we addressed single rater bias by delivering two surveys, to be independently completed by two different managers, to each sampled firm (Podsakoff et al., 2003). The handful of firms that returned both questionnaires showed a high level of internal agreement, suggesting that the data from the remaining single respondents is reliable (Bjornali et al., 2016; Miller et al., 1997). Additionally, we triangulated some of the survey data using information from websites and annual reports, especially for the few publicly listed firms in the sample. Third, we avoided potential CMV by measuring the dependent and predictor variables using different types of data (Chang et al., 2010). Specifically, we measured cost of debt as a rate (\%) and measured political ties using a scale. Fourth, the questions in the survey were strategically ordered to reduce the likelihood of CMV across the independent, dependent and control variables (Barden et al., 2005). By ensuring that questions about the dependent and independent variables did not follow sequentially, we made it difficult for respondents to create variable correlations that could bias their responses (Chang et al., 2010; Wiklund and Shepherd, 2005). Finally, we ruled out the existence of systemic nonresponse bias by using the approach of Armstrong and Overton (1977) to compare early and late-arriving completed surveys. Tests revealed no significant difference for any key items or variables.

We conducted exploratory factor analysis (EFA) to identify the factor structure of the constructs. The EFA yielded four factors (the first factor accounted for $28.79 \%$ of the total variance), therefore suggesting the absence of a single factor in the data (Harman, 1967). We further checked the unidimensionality of the constructs by conducting confirmatory factor analysis 
(CFA) which revealed that a four-factor model $(\mathrm{CFI}=0.96 ; \mathrm{NFI}=0.95, \mathrm{RMSEA}=0.05 ; \mathrm{p}>0.05)$ fits the data better than a onefactor model $(\mathrm{CFI}=0.68 ; \mathrm{NFI}=0.65$, RMSEA $=0.42 ; \mathrm{p}<0.01)$. The measurement items, their respective loadings and T-values, average variance extracted (AVE) and composite reliability (CR) are shown in Table 1. The AVE and CR scores exceed the minimum thresholds of 0.50 and 0.70 respectively (Fornell and Larcker, 1981; Hair et al., 1998), thus confirming reliability of the constructs.

Table 1

Constructs, measurement items and reliability.

\begin{tabular}{|c|c|c|c|}
\hline Construct & Measurement items & Load & T-value \\
\hline \multicolumn{4}{|l|}{ Managerial political ties } \\
\hline \multirow[t]{3}{*}{$(\mathrm{AVE}=0.84 ; \mathrm{CR}=0.94)$} & Spending time dealing with gov't affairs & 0.93 & 19.91 \\
\hline & Investing in building relationships with gov't officials & 0.91 & (Fixed) \\
\hline & Maintaining good relationships with gov't officials & 0.91 & 18.99 \\
\hline \multicolumn{4}{|l|}{ Institutional holding } \\
\hline \multirow[t]{6}{*}{$(\mathrm{AVE}=0.75 ; \mathrm{CR}=0.95)$} & Shares held by Pension funds & 0.94 & (Fixed) \\
\hline & Shares held by Insurance companies & 0.92 & 22.73 \\
\hline & Shares held by Endowment funds & 0.88 & 20.09 \\
\hline & Shares held by Mutual funds & 0.86 & 18.76 \\
\hline & Shares held by Charities & 0.81 & 15.93 \\
\hline & Shares held by Private equity firms & 0.77 & 14.44 \\
\hline \multicolumn{4}{|l|}{ Financial reporting quality } \\
\hline \multirow[t]{4}{*}{$(\mathrm{AVE}=0.73 ; \mathrm{CR}=0.91)$} & Financial reporting done timely & 0.89 & 12.97 \\
\hline & Revenues deferred until verified & 0.88 & 12.69 \\
\hline & Expenses and losses recognised immediately & 0.86 & 12.4 \\
\hline & Financial reports meet acceptable standards & 0.77 & (Fixed) \\
\hline \multirow{5}{*}{$\begin{array}{l}\text { Non-financial disclosure } \\
(\mathrm{AVE}=0.60 ; \mathrm{CR}=0.86)\end{array}$} & & & \\
\hline & Disclosure of conflicts of interest & 0.81 & 10.64 \\
\hline & Disclosure of related party transactions & 0.78 & (Fixed) \\
\hline & Disclosure of anti-corruption policy & 0.78 & 10.32 \\
\hline & Disclosure of external and business risk assessments & 0.72 & 9.51 \\
\hline
\end{tabular}

Furthermore, the Cronbach alphas for the constructs are well above the minimum threshold of 0.70 (Nunnally, 1978), and thus support internal consistency and reliability. We followed the approach of Ambos et al. (2010) and checked discriminant validity by comparing the square root of the average variance extracted (AVE) of each variable with the correlation vbetween pairs of variables. The AVE values are consistently larger than the correlations between the variables, indicating that each construct has more internally extracted variance than the variance it shares with other constructs (Fornell and Larcker, 1981).

\section{Variables and measures}

Independent variable

Without an objective measure of managerial political ties $(\alpha=0.94)$, we followed Li and Zhang (2007), Li and AtuaheneGima (2001) and Guo et al. (2014) and asked respondents to indicate their level of agreement with (a) investing in building ties with government officials (b) spending time dealing with government officials and (c) making efforts to ensure good relations with government officials. These were measured on a scale ranging from (1) "strongly disagree" to (7) "strongly agree".

\section{Dependent variable}

Following Dygryse and Van Cayseele (2000), Bliss and Gul (2012), we measured cost of debt as the interest rates on loans. We asked respondents to state their firms' three-year average interest rate on funds they borrowed from banks operating in Ghana. Any loans from banks outside of Ghana were excluded. Considering how interest rate regimes differ across the world, excluding foreign borrowing allowed for a robust and fair comparison across the firms.

\section{Mediators/moderators}

There is no consensual definition of reporting quality (Chen et al., 2011). Prior studies have measured financial reporting quality ( $\alpha=0.91$ ) using accounting data, specifically accruals quality (Garrett et al., 2014; Filip et al., 2015), but due the lack of accounting data, we measured this variable using a scale. Defining reporting quality as "the usefulness of financial statements to investors, creditors, managers, and all other parties contracting with the firm" (Ball and Shivakumar, 2005, p.84), we asked firms to indicate their level of agreement with four statements, on a scale ranging from (1) "strongly disagree" to (7) "strongly 
agree". Similarly, a scan of the literature revealed that there is no existing scale for measuring non-financial disclosure $(\alpha=0.86)$. Guided by EU Non-financial reporting guidelines, we developed a measure for this variable. Respondents were asked to indicate the extent to which they agree that their firms voluntarily disclose information on related party transactions, conflicts of interests, external risk assessments, anticorruption and bribery. The items were measured using a scale ranging from (1) "strongly disagree" to (7) "strongly agree". Following previous studies (e.g. Abor and Biekpe, 2007), we operationalized board independence as the ratio of independent/non-executive directors to total number of board members. We measured government-owned bank borrowing using a dummy coded 1 for firms that borrowed, in full or part, from the three State bank banks in Ghana and 0 for firms that borrowed exclusively from privately-held banks.

\section{Control variables}

Institutional holding $(\alpha=0.94)$ can give credibility to firms and help lower interest rates. Due to the absence of objective data which other studies used to measure institutional ownership (e.g. Hoskisson et al., 2002), we measured this variable by asking respondents to indicate the extent to which Pension Funds, Mutual Funds, Insurance companies, Charities, and Private Equity Firms hold shares in their companies on a Likert scale ranging from (1) "very low" to (7) "very high". Firms that borrow from multiple banks may benefit low interest rates since competition between the banks may reduce rent extraction and prevent a single bank from charging above-market rates (Dygryse and Van Cayseele, 2000). Conversely, multiple borrowing relationships may signal low borrower quality (Bris and Welch, 2005) and can lead to high interest rates. We measured credit relationships by asking respondents to state the number of banks in Ghana from which their firms have borrowed funds. We measured Collateral value by asking respondents to indicate the perceived value of collateral, in relation to total assets, their firms pledged for loans on a scale from (1) "very low" to (7) "very high". Ownership was defined by a dummy variable, coded 1 for foreign firms (more than $50 \%$ of the firm owned by a foreigner) and 0 for local firms (50\% or more of the firm owned by a local investor). Following previous studies (Acquaah, 2007), Firm age was operationalized as the number of years the firm has been operational in Ghana while firm size was operationalized as the logarithm of the number of employees (after conducting normality tests).

\section{Analysis and results}

The means, standard deviations, and correlation coefficients are shown in Table 2. The correlation matrix reveals significant correlations between the variables. Variance Inflation Factor (VIF) scores are less than 2, and hence support the absence of multicollinearity (Myers, 1990). Table 3 shows results for the direct and moderated effect of political ties on the cost of debt. In Model 1 where the controls are regressed on the dependent variable, institutional holding $(\beta=-0.005, p<0.01)$ and foreign ownership $(\beta=-0.018, p<0.01)$ are negatively associated with interest rates, while collateral $(\beta=-0.004, p<0.05)$ and credit relationships $(\beta=0.010, p<0.01)$ are positively related to interest rates. In Model 3, political ties are significantly and positively related to interest rates $(\beta=0.007, p<0.01)$. This finding supports support $\mathrm{H} 1$, and is consistent with Bliss and Gul (2012) who reported a positive association between political connections and cost of debt in Malaysia.

Table 2

Correlations and descriptive statistics.

\begin{tabular}{|c|c|c|c|c|c|c|c|c|c|c|c|c|c|c|c|c|}
\hline & & Mean & SD & $\begin{array}{l}\text { Cronbach } \\
\text { alpha }\end{array}$ & 1 & 2 & 3 & 4 & 5 & 6 & 7 & 8 & 9 & 10 & 11 & $\begin{array}{l}\text { Largest } \\
\text { VIF }\end{array}$ \\
\hline 1 & $\begin{array}{l}\text { Managerial political } \\
\text { ties }\end{array}$ & 3.90 & 2.19 & 0.94 & 1 & & & & & & & & & & & 1.09 \\
\hline 2 & $\begin{array}{l}\text { Financial reporting } \\
\text { quality }\end{array}$ & 5.83 & 1.19 & 0.91 & $-0.15^{* *}$ & 1 & & & & & & & & & & 1.06 \\
\hline 3 & $\begin{array}{l}\text { Non-financial } \\
\text { disclosure }\end{array}$ & 2.00 & 0.74 & 0.86 & $-0.50^{* * *}$ & $0.24^{* * *}$ & 1 & & & & & & & & & 1.42 \\
\hline 4 & Board independence & 0.15 & 0.13 & - & $-0.18^{* *}$ & 0.04 & 0.09 & 1 & & & & & & & & 1.14 \\
\hline 5 & Institutional holding & 2.08 & 1.51 & 0.94 & 0.06 & 0.10 & -0.04 & $-0.28^{* * *}$ & 1 & & & & & & & 1.1 \\
\hline 6 & Firm age & 19.17 & 12.62 & - & $0.22^{* * *}$ & 0.03 & -0.10 & -0.05 & 0.03 & 1 & & & & & & 1.13 \\
\hline 7 & Firm size & 4.56 & 0.62 & - & 0.00 & 0.07 & 0.04 & $0.13^{*}$ & -0.03 & $0.14^{*}$ & 1 & & & & & 1.05 \\
\hline 8 & Ownership & 0.45 & 0.50 & - & -0.05 & 0.00 & 0.09 & 0.06 & $0.13^{*}$ & 0.12 & 0.11 & 1 & & & & 1.15 \\
\hline 9 & Value of collateral & 4.91 & 1.71 & - & 0.01 & 0.01 & -0.01 & -0.04 & -0.04 & -0.03 & 0.01 & $-0.30^{* *}$ & 1 & & & 1.07 \\
\hline 10 & Credit relationships & 3.82 & 1.57 & - & 0.11 & -0.05 & -0.05 & 0.12 & $-0.28^{* * *}$ & $-0.16^{* *}$ & 0.09 & $-0.13^{*}$ & 0.06 & 1 & & 1.18 \\
\hline 11 & Interest rate & 0.24 & 0.04 & - & $0.45^{* * *}$ & $-0.27^{* * *}$ & $-0.32^{* * *}$ & -0.08 & $-0.30^{* * *}$ & -0.02 & 0.00 & $-0.33^{* * *}$ & $0.22^{* * *}$ & $0.42^{* * *} 1$ & 1 & - \\
\hline
\end{tabular}

Note: $\mathrm{N}=179 ;{ }^{* * *}$ Correlation is significant at the $1 \%$ level (2-tailed); ${ }^{* *}$ Correlation is significant at the $5 \%$ level (2-tailed); ${ }^{*}$ Correlation is significant at the $10 \%$ level (2-tailed).

In Model 5, the interaction between political ties and borrowing from government-owned banks is significant $(\beta=-0.006$, $p<0.01)$. This result indicates that there is a significant difference in the effect of political ties when firms borrow from government-owned banks versus from privately-owned banks. Following the guidelines for the interpretation of interaction 
Table 3

Direct and moderated effects of political ties on cost of debt.

\begin{tabular}{|c|c|c|c|c|c|}
\hline \multirow[t]{2}{*}{ Variables } & \multicolumn{5}{|c|}{ Interest rate } \\
\hline & Model 1 & Model 2 & Model 3 & Model $4^{\mathrm{a}}$ & Model $5^{\mathrm{b}}$ \\
\hline \multicolumn{6}{|l|}{ Control variables } \\
\hline Institutional holding & $-0.005^{* * *}$ & $-0.005^{* * *}$ & $-0.006^{* * *}$ & $-0.006^{* * *}$ & $-0.006^{* * *}$ \\
\hline Firm age & 0.000 & 0.000 & 0.000 & 0.000 & 0.000 \\
\hline Firm size & -0.002 & -0.002 & -0.001 & 0.001 & 0.001 \\
\hline Ownership & $-0.018^{* * *}$ & -0.006 & -0.006 & -0.002 & -0.002 \\
\hline Value of collateral & $0.004^{* *}$ & $0.004^{* * *}$ & $0.004^{* * *}$ & $0.004^{* * *}$ & $0.004^{* * *}$ \\
\hline Credit relationships & $0.010^{* * *}$ & $0.006^{* * *}$ & $0.005^{* * *}$ & $0.005^{* * *}$ & $0.005^{* * *}$ \\
\hline \multicolumn{6}{|l|}{ Moderator variable } \\
\hline Government-owned bank (GOB) & & $-0.040^{* * *}$ & $0.034^{* * *}$ & $-0.037^{* * *}$ & $-0.037^{* * *}$ \\
\hline \multicolumn{6}{|l|}{ Predictor variable } \\
\hline Managerial political ties (MPT) & & & $0.007^{* * *}$ & 0.003 & $0.009^{* * *}$ \\
\hline \multicolumn{6}{|l|}{ Interactions $^{c}$} \\
\hline МРТхРОВ & & & & $0.006^{* * *}$ & \\
\hline MPTxGOB & & & & & $-0.006^{* * *}$ \\
\hline Adjusted $\mathrm{R}^{2}$ & 0.26 & 0.44 & 0.56 & 0.58 & 0.58 \\
\hline Model F & $11.04^{* * *}$ & $19.98^{* * * *}$ & $27.94^{* * *}$ & $26.74^{* * * *}$ & $26.74^{* * *}$ \\
\hline
\end{tabular}

Note: $\mathrm{N}=179 .{ }^{* * *} \mathrm{p}<0.01 ;{ }^{* *} \mathrm{p}<0.05 ;{ }^{*} \mathrm{p}<0.1$ (two-tailed significance tests).

a In Model 4, GOB was reverse-coded before creating interaction term MPTXPOB.

b Consistent with reverse coding, Model 5 is similar to Model 4, with the exception of the Constant, Interaction and MPT.

${ }^{\mathrm{c}}$ Before creating the interactions terms, MPT was mean centred.

terms involving dummy variables (Hardy, 1993), ${ }^{1}$ we interpreted the coefficient for MPT as the effect of political ties on interest rates when $\mathrm{GOB}=0$ (i.e. borrowing from private-owned banks). This result is significant (Model 5: $\beta=0.009, p<0.01$ ) and shows that politically connected firms are charged high rates when they borrow from private-owned banks, hence providing support for hypothesis $2 \mathrm{~b}$. To estimate the moderating effect of borrowing from government-owned banks, we followed the approach of Hadani and Schuler (2013) and reverse-recoded our dummy variable government-owned bank so that borrowing from government banks $=0$ while borrowing from private-owned banks $=1$. The interaction between political ties and borrowing from privately-owned banks (POB) is significant (Model 4: $\beta=0.006, p<0.05$ ) but the coefficient for MPT, which represents the effect of political ties when $\mathrm{POB}=0$ (i.e. borrowing from government-owned banks), is insignificant $(\beta=0.003, p>0.1)$. This result provides partial support for hypothesis $2 \mathrm{a}$, in the sense that the previously positive association between political ties and the cost of debt (Model 3: $\beta=0.007, p<0.01$ ) becomes insignificant when connected firms borrow from government-owned banks. Fig. 1 shows the plot of the moderation effects.

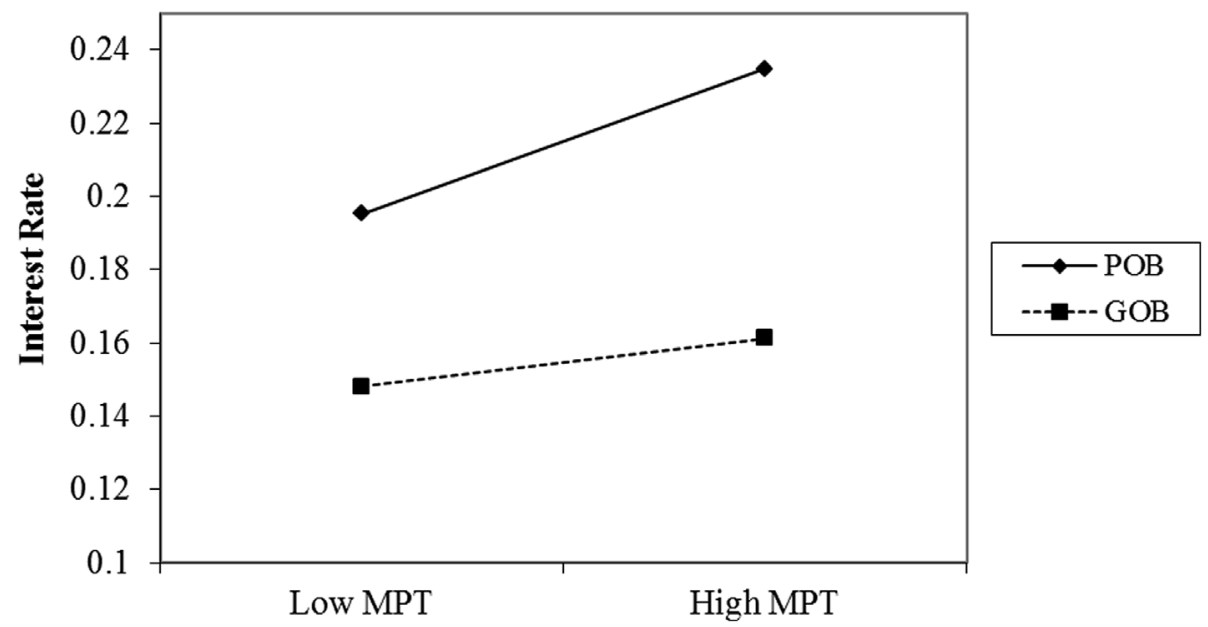

Fig. 1. The moderation effect of bank ownership.

\footnotetext{
${ }^{1}$ When a model contains an interaction term which is the product of a continuous variable and a dummy variable, coefficients on the lower-order continuous term are interpreted as the effect of the continuous variable only and only when the dummy variable is 0 . In effect, the result corresponds with the group $=0$.
} 
To test mediation, we followed the general recommendations of Baron and Kenny (1986). The results, presented in Table 3, show that the relationships between political ties and each of the mediator variables are significant (Models 2 to 4 ). Precisely, the results reveal that political ties are negatively related to financial reporting quality (Model 2: $\beta=-0.096, p<0.05$ ), nonfinancial disclosure (Model 3: $\beta=-0.169, p<0.01$ ), and board monitoring (Model 4: $\beta=-0.009, p<0.05$ ), suggesting poor governance in connected firms, as predicted.

As the mediator variables are significantly related to the independent variable, they are included in the next stages where their association with interest rates is tested together with the independent variable. The results for these next stages are shown in Models 5-8. Non-financial disclosure and board independence are insignificant, and thus do not mediate political ties in credit markets. Therefore, we did not find support for $\mathrm{H} 4$ and H5. Only financial reporting quality has a significant association with interest rates (Model 5: $\beta=-0.006, p<0.01$ ). However, caution must be exercised in the interpretation of this finding. For mediation to exist, "the effect of the independent variable on the dependent variable must be less ... when the mediating variable is controlled (Baron and Kenny, 1986: 1177). Therefore, the size and/or significance of the coefficient for political ties should be lower in Model 5 where it is estimated together with financial reporting quality. Our results do not show a change in the coefficient/significance of political ties between Model 1 and Model 5, and hence do not provide strong support for mediation.

To further probe and check the robustness of the results, we conducted Structural Equation Modelling (SEM) without the controls. Consistent with the regression results, SEM shows that political ties are negatively related to financial reporting quality $(\beta=-0.086, p<0.05)$, disclosure of non-financial information $(\beta=-0.170, p<0.01)$ and board independence $(\beta=-0.010, p<0.05)$. Of the three mediators, only financial reporting quality has a significant effect on the cost of debt ( $\beta=-0.007, p<0.01)$ but because direct effect of political ties is also significant $(\beta=0.007, p<0.01)$, the results suggest the presence of partial mediation. Though the indirect effect - which measures the amount of mediation - is weakly significant ( $\beta=0.001, p<0.1$ ), it lies exactly on the lower bound of the $95 \%$ bias-corrected confidence interval (i.e. $0.001-0.003$ ). This evidence confirms why the coefficient for political ties did not change between Models 1 and 5 (Table 4). Taking the results together, we did not find support for mediation and for H3.

Table 4

Mediation results.

\begin{tabular}{|c|c|c|c|c|c|c|c|c|}
\hline & \multicolumn{8}{|c|}{ Dependent variable } \\
\hline & $\begin{array}{l}\text { Interest rate } \\
\text { (Model 1) }\end{array}$ & $\begin{array}{l}\text { Financial rep } \\
\text { quality } \\
\text { (Model 2) }\end{array}$ & $\begin{array}{l}\text { Non-financial } \\
\text { disclosure } \\
\text { (Model 3) }\end{array}$ & $\begin{array}{l}\text { Board } \\
\text { independence } \\
\text { (Model 4) }\end{array}$ & $\begin{array}{l}\text { Interest rate } \\
\text { (Model 5) }\end{array}$ & $\begin{array}{l}\text { Interest rate } \\
\text { (Model 6) }\end{array}$ & $\begin{array}{l}\text { Interest rate } \\
\text { (Model 7) }\end{array}$ & $\begin{array}{l}\text { Interest rate } \\
\text { (Model 8) }\end{array}$ \\
\hline \multicolumn{9}{|l|}{ Independent variable } \\
\hline $\begin{array}{l}\text { Managerial political ties } \\
\text { Mediator variables }\end{array}$ & $0.008^{* * *}$ & $-0.096^{* *}$ & $-0.169^{* * *}$ & $-0.009^{* *}$ & $0.008^{* * *}$ & $0.008^{* * *}$ & $0.008^{* * *}$ & $0.007^{* * *}$ \\
\hline Financial reporting quality & & & & & $-0.006^{* * *}$ & & & $-0.005^{* *}$ \\
\hline Non-financial disclosure & & & & & & -0.003 & & -0.002 \\
\hline Board independence & & & & & & & -0.023 & -0.022 \\
\hline \multicolumn{9}{|l|}{ Control variables } \\
\hline Institutional holding & $-0.007^{* * *}$ & 0.093 & -0.007 & $-0.022^{* * *}$ & $-0.006^{* * *}$ & $-0.007^{* * *}$ & $-0.007^{* * *}$ & $-0.006^{* * *}$ \\
\hline Firm age & 0.000 & 0.006 & 0.000 & 0.000 & 0.000 & 0.000 & 0.000 & 0.000 \\
\hline Firm size & -0.001 & 0.138 & 0.034 & 0.024 & 0.000 & -0.001 & 0.000 & 0.001 \\
\hline Ownership & $-0.016^{* * *}$ & -0.082 & 0.108 & 0.020 & $-0.016^{* * *}$ & $-0.015^{* * *}$ & $-0.015^{* * *}$ & $-0.016^{* * *}$ \\
\hline Value of collateral & $0.004^{* *}$ & 0.004 & 0.009 & -0.002 & $0.004^{* *}$ & $0.004^{* *}$ & $0.004^{* *}$ & $0.004^{* *}$ \\
\hline Credit relationships & $0.007^{* * *}$ & 0.003 & 0.005 & 0.005 & $0.007^{* * *}$ & $0.007^{* * *}$ & $0.007^{* * *}$ & $0.007^{* * *}$ \\
\hline \multicolumn{9}{|l|}{ Model summary } \\
\hline F value & $19.64^{* * *}$ & 1.18 & $8.51^{* * *}$ & $3.69^{* * *}$ & $18.70^{* * *}$ & $17.19^{* * *}$ & $17.36^{* * *}$ & $15.01^{* * *}$ \\
\hline Adjusted R2 & 0.44 & 0.01 & 0.23 & 0.10 & 0.46 & 0.44 & 0.44 & 0.46 \\
\hline
\end{tabular}

Note: $\mathrm{N}=179 ;{ }^{* * *}$ Correlation is significant at the $1 \%$ level (2-tailed); ${ }^{* *}$ Correlation is significant at the $5 \%$ level (2-tailed); ${ }^{*}$ Correlation is significant at the $10 \%$ level (2-tailed). Results shown in three decimal places in order not to suppress effects.

\section{Discussion and conclusion}

This study has explored a nascent topic and has shed light on the contested effect and the under-explored mechanisms of political ties (Rajwani and Liedong, 2015). The findings reveal a positive relationship between political ties and cost of debt, which becomes more pronounced when connected firms borrow from privately-owned banks and weaker when they borrow from government-owned banks. Essentially, politically connected firms are perceived to be risky (Bliss and Gul, 2012) and fraught with moral hazard problems (Chaney et al., 2011), but due to the nature of the agency relationship existing between politicians and State enterprises, government-owned banks tend overlook these problems in their credit assessments.

The findings also reveal a negative relationship between political ties and the governance variables, namely financial reporting quality, non-financial disclosure and board independence. These results are consistent with prior studies in two ways. First, concerns have been documented about the proneness of politically connected firms to financial misbehaviour (Guedhami et al., 2014; Gul, 2006). These firms are more likely to manipulate their accounts in order to conceal politically 
motivated malfeasances (Effiezal et al., 2011), and they are emboldened to behave inappropriately because of the protection they receive from politicians. Their malpractices are rarely detected and legal systems are influenced to overlook related agency problems (Correia, 2014; Sun et al., 2016). Second, evidence shows that the quality of accounting information disclosed by connected firms is lower when compared to that of non-connected firms (Chaney et al., 2011).

Contrary to our prediction, financial reporting quality, disclosure of non-financial information and board independence do not mediate the relationship between political ties and the cost of debt. Cognizant of the institutional and governance challenges in Ghana, it is perhaps still early for banks to factor financial and non-mandatory information into their loan pricing decisions, especially for connected firms which often enjoy political and institutional protection (Park and Luo, 2001; Xin and Pearce, 1996). To the extent that connected firms are protected by the very agencies responsible for enforcing financial and regulatory compliance (Chaney et al., 2011), it is possible that banks' pricing of loans to these firms is not influenced by the quality of financial reporting. Moreover, low internet penetration in Africa and lack of technological resources make it difficult for firms to use online platforms to disclose non-financial information. Hence, even though connected firms do not disclose this information, banks rarely take it into account when setting interest rates. Arguably, most firms in Africa could be excluded from credit if disclosure of non-financial information is a stringent yardstick for creditworthiness. Similarly, in Ghana where most of the firms are privately held and board culture is generally poor (Abor and Biekpe, 2007), it is not surprising that board independence is not uniquely considered by banks when pricing loans to connected firms.

Altogether, the results demonstrate that in emerging countries, the lack of strong institutions to support and enforce good corporate governance (Young et al., 2008) coupled with weak checks and balances in political systems allow politically connected firms to develop poor governance cultures to conceal rent appropriation and evade stakeholder scrutiny. Even though connected firms are charged high interest rates, their poor governance does not seem to mediate their performance in credit markets. In other words, connected firms are able to get away with their poor governance in credit markets where they should be penalized. Consequently, it is plausible to argue that moral hazard in connected firms is reinforced by the failure of banks and other financial institutions to penalize these firms for their illegal and unethical behaviour.

This study contributes to CPA literature in significant ways. First, it extends CPA research to credit markets in an empirically under-researched context. The effect of political ties on cost of debt has not received adequate attention, despite the importance of loan finance for firms (Adomako et al., 2016; Beck and Demirguc-Kunt, 2006). Moreover, findings from the few studies that have examined this topic are mixed and inconclusive. While there is a consensus that political connections enhance access to finance in developed and emerging markets alike (e.g. Claessens et al., 2008; Faccio, 2010; Houston et al., 2014; Khwaja and Mian, 2005), there is no agreement about the effect of these connections on loan prices. For example, whereas research in the developed country context suggests that political connections lead to lower costs of debt (Houston et al., 2014; Infante and Piazza, 2014), some studies in emerging countries find a negative effect of political ties on the cost of debt (e.g. Bliss and Gul, 2012).

According to Houston et al. (2014), connected firms receive preferential treatment in credit markets through the borrower channel. In other words, bankers are aware of the influence of political connections on profitability, performance (Goldman et al., 2009; Hillman, 2005) and policy risk exposure (Bradley et al., 2016), and hence hold positive perceptions about the creditworthiness of connected firms. They argue that the borrower channel is more relevant in developed markets where strong institutions make it difficult for politicians to direct bank lending. We argue that, indeed, the borrower channel may be limited to developed contexts. While bankers in emerging countries may know that politically connected firms have greater access to scarce resources and business opportunities, they are also fully aware of the potential risks and hazards inherent in these firms (Bliss and Gul, 2012). As such, they charge higher interest rates to compensate for the underlying riskiness caused by the connected firms' moral hazard which is less likely to be checked by weak institutions in emerging countries.

Moreover, the enforcement of creditor rights in emerging countries is weak (Claessens and Yurtoglu, 2013). Generally, in countries where there is weak enforcement of creditor rights, banks charge high loan rates (Bae and Goyal, 2009). Banks may even charge higher rates due to the negligible "power" they have to enforce loan obligations against connected firms which enjoy high political support. High interest charges will compensate banks for their limited ability to recover loans in events of default. The problem of weak creditor rights is more serious for privately-owned banks, mainly as these banks usually do not have as much political clout as government-owned banks; hence their high interest charges reflect their curtailed loan recovery power. This study therefore sheds more light on the conditional worth of political ties in emerging credit markets.

Second, this study affords rich insights into the dynamic value of political ties in general, and the dark side of political activity in particular (Sun et al., 2016). It lends support to the view that political ties do not only reduce the strategic agility of firms (Sun et al., 2010), but they are also costly and inimical to firm performance (Hadani and Schuler, 2013; Park and Luo, 2001; Okhmatovskiy, 2010). In emerging countries especially, regime changes can turn previously valuable political ties into liabilities (Leuz and Oberholzer-Gee, 2006; Siegel, 2007; Sun et al., 2012) and this can have ripple effects on other organizational outcomes, such as the cost of debt. In Africa, the acrimony and vindictiveness of politics causes new regimes to persecute and discriminate against firms that were connected to erstwhile regimes, mainly to discredit previous political elites and also to gain popular legitimacy (Henisz and Zelner, 2003). Essentially, having "wrong friends at the wrong time" reduces shareholder value. Our study therefore suggests that the dynamism of political embeddedness results in temporariness of political capital, hence the reason why the borrower channel (Houston et al., 2014) may not be relevant in emerging countries. Further, this study shows the darker side of political ties. It joins the few studies that have addressed the influence of political connections on corporate governance and agency relationships (e.g. Aggarwal et al., 2012; Chaney et al., 2011; 
Hadani and Schuler, 2013; Guedhami et al., 2014; Sun et al., 2016) and confirms the vaguely-held view that political activity leads to poor corporate governance.

Third, this study attempts to enhance our understanding of how political ties affect cost of debt. One of the notable shortcomings in CPA literature is the limited treatise of mediating mechanisms (Guo et al., 2014). In the past, most researchers were mainly interested in answering the "what" questions but not the "how" questions (Liedong et al., 2015). Our findings show that even though political ties lead to poor governance, poor governance does not seem to mediate the impact of ties on the cost of debt. This phenomenon further reinforces and accentuates the moral hazard problem, and portrays the factors underlying the poor quality of financial information disclosed by connected firms (Chaney et al., 2011). In sum, this study's focus on the mediation provides a better understanding of the dynamics and implications of governance in connected firms.

The insightful findings of this study have practical implications. They suggest that politically connected firms in emerging countries are poorly governed. Managers of these firms should therefore strengthen corporate governance in order to quell the negative views of financial misconduct and corruption that are often associated with deep political embeddedness in weak institutional environments. Additionally, regulators will have to increase the monitoring and scrutiny of corporate governance in politically connected firms, mainly as these firms are more likely to indulge in inappropriate behaviour.

\section{Limitations, future research and conclusion}

Beside the contributions, this study has limitations. First, it uses cross-sectional data and is therefore prone to endogeneity problems. We addressed some of the sources of endogeneity such as autocorrelation of error terms. We also designed the survey to collect responses within a three-year frame (Mesquita and Lazzarini, 2008; White et al., 2015), hence we allowed adequate time for the effect of political ties on the cost of debt to be observed. Further, we tried to lag the dependent variable by collecting data from same firms in 2015. Though we experienced sample attrition (which made the data unusable for multivariate analyses), there were no significant differences between the data from the two phases, which suggests that our analyses do not suffer from reverse causality. However, readers should be cautious when interpreting the findings, since other sources of endogeneity such as measurement errors and omitted variables could still influence the results. We recommend future research to use longitudinal designs and secondary data where possible.

Second, the scope of this study is limited to three governance mediators. We therefore encourage future research to continue to explore the role of agency in the cost of debt, especially governance indicators such as board audit committees, shareholder rights, and CEO duality within the context of Africa in general and Ghana in particular. Importantly, since none of the mediators of this study is significant, it would be insightful to investigate the other mechanisms influencing banks' lending decisions.

Third, we acknowledge that there is a dark side of political activity (Doh et al., 2012). For instance, prior research has noted that politically connected firms obtain favours from banks through threats and coercion from politicians (Khwaja and Mian, 2005). We encourage studies to build on this current study and investigate whether such dark agency mechanisms are at play when connected firms borrow from banks. We contend that this line of research will be best suited to emerging countries where weak institutions make it easier for governments to use their unchecked power to influence bank lending (Houston et al., 2014). Political interference could hamper bank due diligence, leading to punitive interest charges. We therefore believe future research could contribute to CPA literature and agency theory by exploring mediating mechanisms from the over-looked supply-side of credit markets - the bankers.

In conclusion, this study contributes to a deeper understanding of the mediating mechanisms through which political ties affect outcomes in credit markets. The findings and conclusions are not only important for CPA researchers, but they are also useful to practitioners and regulators, especially in Ghana and other emerging countries.

\section{References}

Aboagye, A.Q.Q., Akoena, S.K., Antwi-Asare, T., Gockel, A.F., 2008. Explaining interest rate spreads in Ghana. Afr. Dev. Rev. $20,378-399$.

Abor, J., 2007. Corporate governance and financing decisions of Ghanaian listed firms. Corp. Gov. 7, 83-92.

Abor, J., Biekpe, N., 2007. Corporate governance, ownership structure and performance of SMEs in Ghana: implications for financing opportunities. Corp. Gov. Int. J. Eff. Board Perform. 7, 288-300.

Abor, J., Fiador, V., 2013. Does corporate governance explain dividend policy in Sub-Saharan Africa? Int. J. Law Manag. 55, $201-225$.

Acquaah, M., 2007. Managerial social capital, strategic orientation, and organizational performance in an emerging economy. Strat. Manage. J. 28, $1235-1255$.

Adomako, S., Danso, A., Ofori-Damoah, J., 2016. The moderating influence of financial literacy on the relationship between access to finance and firm growth in Ghana. Venture Cap. 18, 43-61.

Aggarwal, R.K., Meschke, F., Wang, T.Y., 2012. Corporate political donations: investment or agency? Bus. Polit. 14, 1649-3569.

Agyeman, O.S., Aboagye, E., Ahali, A.Y.O., 2013. Prospect and challenges of corporate governance in Ghana. Int. J. Sci. Res. Publ. 3, 1-9.

Ambos, T.C., Andersson, U., Birkinshaw, J., 2010. What are the consequences of initiative-taking in multinational subsidiaries? J. Int. Bus. Stud. 41, 1099-1118.

Amoako-Gyampah, K., Boye, S.S., 2001. Operations strategy in an emerging economy: the case of the Ghanaian manufacturing industry. J. Oper. Manag. 19, 59-79.

Anderson, R.C., Mansi, S.A., Reeb, D.M., 2004. Board characteristics, accounting report integrity, and the cost of debt. J. Account. Econ. $37,315-342$.

Armstrong, J.S., Overton, T.S., 1977. Estimating nonresponse bias in mail surveys. J. Mark. Res. 14, 396-402.

Aryeetey, E., 1998. Informal Finance for Private Sector Development in Africa. African Development Bank Working Paper Series, No. 41.

Bae, K., Goyal, V.K., 2009. Creditor rights, enforcement, and bank loans. J. Finance 64, 823-860.

Ball, R., Shivakumar, L., 2005. Earnings quality in UK private firms: comparative loss recognition timeliness. J. Account. Econ. $39,83-128$.

Barden, J.Q., Steensma, H.K., Lyles, M.A., 2005. The influence of parent control structure on parent conflict in Vietnamese international joint ventures: an organizational justice-based contingency approach. J. Int. Bus. Stud. 36, 156-174. 
Bargeron, L.L., Lehn, K.M., Zutter, C.J., 2010. Sarbanes-Oxley and corporate risk-taking. J. Account. Econ. 49, $34-52$.

Baron, R.M., Kenny, D.A., 1986. The moderator-mediator variable distinction in social psychological research: conceptual, strategic, and statistical considerations. J. Personality Soc. Psychol. 51, 1173-1182.

Barth, J.R., Lin, C., Lin, P., Song, F.M., 2009. Corruption in bank lending to firms: cross-country micro evidence on the beneficial role of competition and information sharing. J. Financial Econ. 91, 361-388.

Beasley, M.S., 1996. An empirical analysis of the relation between the board of director composition and financial statement fraud. Account. Rev. 71, $443-465$

Beck, T., Demirguc-Kunt, A., 2006. Small and medium-size enterprises: access to finance as a growth constraint. J. Bank. Finance 30, 2931-2943.

Beck, T., Demirgüç-Kunt, A., Laeven, L., Maksimovic, V., 2006. The determinants of financing obstacles. J. Int. Money Finance 25, $932-952$.

Bharath, S.T., Sunder, J., Sunder, S.V., 2008. Accounting quality and debt contracting. Account. Rev. 83, 1-28.

Bhojraj, S., Sengupta, P., 2003. Effect of corporate governance on bond ratings and yields: the role of institutional investors and outside directors. J. Bus. 76, 455-475.

Bjornali, E.S., Knockaert, M., Erikson, T., 2016. The impact of top management team characteristics and board service involvement on team effectiveness in high-tech start-ups. Long Range Plan. 49, 447-463.

Bliss, M.A., Gul, F.A., 2012. Political connection and cost of debt: some Malaysian evidence. J. Bank. Finance 36, $1520-1527$.

Bokpin, G.A., 2009. An examination of the governance practices of Ghanaian media institutions. Corp. Gov. Int. J. Eff. Board Perform. 9, 600-609.

Boyd, B.K., 1994. Board control and CEO compensation. Strat. Manag. J. 15, 335-335.

Bradley, D., Pantzalis, C., Yuan, X., 2016. Policy risk, corporate political strategies, and the cost of debt. J. Corp. Finance 40, $254-275$.

Brandt, L., Li, H., 2003. Bank discrimination in transition economies: ideology, information, or incentives? J. Comp. Econ. $31,387-413$.

Bris, A., Welch, I., 2005. The optimal concentration of creditors. J. Finance 60, 2193-2212.

Butler, A.W., Fauver, L., Mortal, S., 2009. Corruption, political connections, and municipal finance. Rev. Financ. Stud. 22, 2873-2905.

Chaney, P.K., Faccio, M., Parsley, D., 2011. The quality of accounting information in politically connected firms. J. Account. Econ. 51, 58-76.

Chang, S.J., Witteloostuijn, A., Eden, L., 2010. From the Editors: common method variance in international business research. J. Int. Bus. Stud. $41,178-184$.

Chen, F., Ole-Kristian, H., Li, Q., Wang, X., 2011. Financial reporting quality and investment efficiency of private firms in emerging markets. Account. Rev. 86, $1255-1288$

Chen, Y., Shen, C., Lin, C., 2014. The benefits of political connection: evidence from individual bank-loan contracts. J. Financ. Serv. Res. 45, $287-305$.

Claessens, S., Feijen, E., Laeven, L., 2008. Political connections and preferential access to finance: the role of campaign contributions. J. Financ. Econ. 88, 554-580.

Claessens, S., Yurtoglu, B.B., 2013. Corporate governance in emerging markets: a survey. Emerg. Mark. Rev. 15, 1-33.

Correia, M.M., 2014. Political connections and SEC enforcement. J. Account. Econ. 57, 241-262.

Decker, S., 2011. Corporate political activity in less developed countries: the volta river project in Ghana, $1958-66$. Bus. Hist. 53, $993-1017$.

Dinc, I.S., 2005. Politicians and banks: political influences on government-owned banks in emerging markets. J. Financ. Econ. 77, 453-479.

Doh, J.P., Lawton, T.C., Rajwani, T., 2012. Advancing nonmarket strategy research: institutional perspectives in a changing world. Acad. Manag. Perspect. 26, $22-39$.

Dygryse, H., Van Cayseele, P., 2000. Relationship lending within a bank-based system: evidence from European small business data. J. Financ. Intermediation 9, 90-109.

Effiezal, A.A., Mazlina, M.Z., Kieran, J., 2011. Political connections, corporate governance and audit fees in Malaysia. Manag. Audit. J. 26, 393-418.

Eisenhardt, K.M., 1989. Agency theory: an assessment and review. Acad. Manag. Rev. 14, 57-74.

Faccio, M., Masulis, R.W., McConnell, J.J., 2006. Political connections and corporate bailouts. J. Finance 61, $2597-2635$.

Faccio, M., 2010. Differences between politically connected and nonconnected firms: a cross-country analysis. Financ. Manag. 39, 905-928.

Filip, A., Labelle, R., Rousseau, S., 2015. Legal regime and financial reporting quality. Contemp. Account. Res. 32, $280-307$.

Firth, M., Rui, O.M., Wu, W., 2011. The effects of political connections and state ownership on corporate litigation in China. J. Law Econ. $54,573-607$.

Fornell, C., Larcker, D.F., 1981. Evaluating structural equation models with unobservable variables and measurement error. J. Mark. Res. 18, 39-50.

Francis, B., Hasan, I., Koetter, M., Wu, Q., 2012. Corporate boards and bank loan contracting. J. Financ. Res. 35, 521-552.

Fraser, D.R., Zhang, H., Derashid, C., 2006. Capital structure and political patronage: the case of Malaysia. J. Bank. Finance 30, $1291-1308$.

Garrett, J., Hoitash, R., Prawitt, D.F., 2014. Trust and financial reporting quality. J. Account. Res. 52, $1087-1125$.

George, G., Corbishley, C., Khayesi, J.N.O., Haas, M.R., Tihanyi, L., 2016. Bringing Africa in: promising directions for management research. Acad. Manag. J. 59, $377-393$.

Goldman, E., Rocholl, J., So, J., 2009. Do politically connected boards affect firm value? Rev. Financ. Stud. 22, 2331-2360.

Guedhami, O., Pittman, J.A., Saffar, W., 2014. Auditor choice in politically connected firms. J. Account. Res. 52, $107-162$.

Gul, F.A., 2006. Auditors' response to political connections and cronyism in Malaysia. J. Account. Res. 44, $931-963$.

Guo, H., Xu, E.M., Jacobs, M., 2014. Managerial political ties and firm performance during institutional transitions: an analysis of mediating mechanisms. J. Bus. Res. 67, 116-127.

Hadani, M., Schuler, D.A., 2013. In search of El Dorado: the elusive financial returns on corporate political investments. Strat. Manag. J. 34, 165-181.

Hair, J.F., Anderson, R.E., Tatham, R.L., Black, W.C., 1998. Multivariate Data Analysis, fifth ed. Pearson Education, Delhi, India.

Hardy, M.A., 1993. Regression with Dummy Variables (Quantitative Applications in the Social Sciences). Sage, Newbury Park, CA.

Harman, H.H., 1967. Modern Factor Analysis. University of Chicago Press, Chicago, IL.

Henisz, W.J., Zelner, B.A., 2003. The strategic organization of political risks and opportunities. Strateg. Organ. 1, 451-460.

Hillman, A.J., 2005. Politicians on the board of directors: do connections affect the bottom line? J. Manag. 31, 464-481.

Hillman, A.J., Zardkoohi, A., Bierman, L., 1999. Corporate political strategies and firm performance: indications of firm specific benefits from personal service in the US government. Strat. Manag. J. 20, 67-81.

Hinkin, T.R., 1995. A review of scale development practices in the study of organizations. J. Manag. 21, 967-988.

Holder-Webb, L., Sharma, D.S., 2010. The effect of governance on credit decisions and perceptions of reporting reliability. Behav. Res. Account. 22, $1-20$.

Hoskisson, R.E., Eden, L., Lau, C.M., Wright, M., 2000. Strategy in emerging economies. Acad. Manag. J. 43, $249-267$.

Hoskisson, R.E., Hitt, M.A., Johnson, R.A., Grossman, W., 2002. Conflicting voices: the effects of institutional ownership heterogeneity and internal governance on corporate innovation strategies. Acad. Manag. J. 45, 697-716.

Houston, J.F., Jiang, L., Lin, C., Ma, Y., 2014. Political connections and the cost of bank loans. J. Account. Res. 52, $193-243$.

Infante, L., Piazza, M., 2014. Political connections and preferential lending at local level: some evidence from the Italian credit market. J. Corp. Finance 29, $246-262$.

Johnson, S., Mitton, T., 2003. Cronyism and capital controls: evidence from Malaysia. J. Financ. Econ. 67, 351 -382.

Khwaja, A.I., Mian, A., 2005. Do lenders favor politically connected Firms? Rent provision in an emerging financial market. Q. J. Econ. $120,1371-1411$.

La Porta, R., Lopez-De-Silanes, F., Shleifer, A., 2002. Government ownership of banks. J. Finance 57, $265-301$.

Lawton, T., McGuire, S., Rajwani, T., 2013a. Corporate political activity: a literature review and research agenda. Int. J. Manag. Rev. 15, 86-105.

Lawton, T., Rajwani, T., Doh, J., 2013b. The antecedents of political capabilities: a study of ownership, cross-border activity and organization at legacy airlines in a deregulatory context. Int. Bus. Rev. 22, 228-242.

Leuz, C., Oberholzer-Gee, F., 2006. Political relationships, global financing, and corporate transparency: evidence from Indonesia. J. Financial Econ. 81, 411-439.

Leuz, C., Nanda, D., Wysocki, P.D., 2003. Earnings management and investor protection: an international comparison. J. Financ. Econ. 69, 505-527.

Li, H., Atuahene-Gima, K., 2001. Product innovation strategy and the performance of new technology ventures in China. Acad. Manag. J. 44, $1123-1134$. 
Li, H., Zhang, Y., 2007. The role of managers' political networking and functional experience in new venture performance: evidence from China's transition economy. Strategic Manag. J. 28, 791-804.

Li, J.J., Zhou, K.Z., 2010. How foreign firms achieve competitive advantage in the Chinese emerging economy: managerial ties and market orientation. J. Bus. Res. 63, 856-862.

Liedong, T.A., Ghobadian, A., Rajwani, T., O'Regan, N., 2015. Toward a view of complementarity: trust and policy influence effects of corporate social responsibility and corporate political activity. Group Organ. Manag. 40, 405-427.

Lin, C., Chen, Y., Yen, J., 2014. On the determinant of bank loan contracts: the roles of borrowers' ownership and board structures. Q. Rev. Econ. Finance 54, $500-512$.

Luiz, J., Stewart, C., 2014. Corruption, south african multinational enterprises and institutions in Africa. J. Bus. Ethics 124, $383-398$.

Luo, Y., 2004. A coopetition perspective of MNC-host government relations. J. Int. Manag. 10, 431-451.

Luo, Y., 2001. Toward a cooperative view of MNC-host government relations: building blocks and performance implications. J. Int. Bus. Stud. 32 , $401-420$.

Luo, Y., Zhao, H., 2013. Doing business in a transitional society: economic environment and relational political strategy for multinationals. Bus. Soc. 52, $515-549$.

Mellahi, K., Mol, M.J., 2015. Africa is just like every other place, in that it is unlike any other place. Afr. J. Manag. 1, $201-209$.

Mellahi, K., Frynas, J.G., Sun, P., Siegel, D., 2016. A review of the nonmarket strategy literature: toward a multi-theoretical integration. J. Manag. 42, $143-173$.

Mensah, S., Abor, J.Y., 2014. Agency conflict and bank interest spreads in Ghana. Afr. Dev. Rev. 26, 549-560.

Mesquita, L.F., Lazzarini, S.G., 2008. Horizontal and vertical relationships in developing economies: implications for SMEs' access to global markets. Acad. Manag. J. 51, 359-380.

Miller, C.C., Cardinal, L.B., Glick, W.H., 1997. Retrospective reports in organizational research: a reexamination of recent evidence. Acad. Manag. J. 40, $189-204$.

Myers, R., 1990. Classical and Modern Regression with Application, second ed. Duxbury, Boston, MA.

Nell, P.C., Puck, J., Heidenreich, S., 2015. Strictly limited choice or agency? Institutional duality, legitimacy, and subsidiaries' political strategies. J. World Bus. $50,302-311$

Nunnally, J.C., 1978. Psychometric Theory. McGraw-Hill, New York.

Okhmatovskiy, I., 2010. Performance implications of ties to the government and SOEs: a political embeddedness perspective. J. Manag. Stud. 47, $1020-1047$.

Onder, Z., Ozyildirim, S., 2011. Political connection, bank credits and growth: evidence from Turkey. World Econ. 34, $1042-1065$.

Park, S.H., Luo, Y., 2001. Guanxi and organizational dynamics: organizational networking in Chinese firms. Strategic Manag. J. 22 , $455-477$.

Peng, M.W., Luo, Y., 2000. Managerial ties and firm performance in a transition economy: the nature of a micro-macro link. Acad. Manag. J. 43, 486-501.

Peng, M.W., 2004. Outside directors and firm performance during institutional transitions. Strat. Manag. J. 25, 453-471.

Podsakoff, P.M., MacKenzie, S.B., Jeong-Yeon, L., Podsakoff, N.P., 2003. Common method biases in behavioral research: a critical review of the literature and recommended remedies. J. Appl. Psychol. 88, 879-903.

Rajwani, T., Liedong, T.A., 2015. Political activity and firm performance within nonmarket research: a review and international comparative assessment. J. World Bus. 50, 273-283.

Rashid, A., 2015. Revisiting agency theory: evidence of board independence and agency cost from Bangladesh. J. Bus. Ethics 130, 181-198.

Robson, P., Akuetteh, C., Stone, I., Westhead, P., Wright, M., 2013. Credit-rationing and entrepreneurial experience: evidence from a resource deficit context. Entrepren. Reg. Dev. 25, 349-370.

Rosenstein, S., Wyatt, J.G., 1990. Outside directors, board independence, and shareholder wealth. J. Financ. Econ. 26, 175-191.

Saeed, A., Belghitar, Y., Clark, E., 2015. Political connections and leverage: firm-level evidence from Pakistan. Manag. Decis. Econ. $36,364-383$.

Sapienza, P., 2004. The effects of government ownership on bank lending. J. Financ. Econ. 72, 357-384.

Schuler, D.A., Schnietz, K.E., Baggett, L.S., 2002. Determinants of foreign trade mission participation: an analysis of corporate political and trade activities. Bus. Soc. 41, 6-35.

Sheng, S., Zhou, K.Z., Li, J.J., 2011. The effects of business and political ties on firm performance: evidence from China. J. Mark. 75, $1-15$.

Shirodkar, V., Mohr, A., 2015. Resource tangibility and foreign firms' corporate political strategies in emerging economies: evidence from India. Manag. Int. Rev. 55, 801-825.

Shleifer, A., Vishny, R.W., 1998. The Grabbing Hand: Government Pathologies and Their Cures. Harvard University Press, Cambridge, MA.

Siegel, J., 2007. Contingent political capital and international alliances: evidence from South Korea. Adm. Sci. 0. 52, 621-666.

Simpson, S.N.Y., 2014. Boards and governance of state-owned enterprises. Corp. Gov. Int. J. Eff. Board Perform. 14, $238-251$.

Sun, P., Hu, H.W., Hillman, A.J., 2016. The dark side of board political capital: enabling blockholder rent appropriation. Acad. Manag. J. 59, 1801-1822.

Sun, P., Mellahi, K., Thun, E., 2010. The dynamic value of MNE political embeddedness: the case of the Chinese automobile industry. J. Int. Bus. Stud. 41, $1161-1182$

Sun, P., Mellahi, K., Wright, M., 2012. The contingent value of corporate political ties. Acad. Manag. Perspect. 26, 68-82.

Tsamenyi, M., Enninful-Adu, E., Onumah, J., 2007. Disclosure and corporate governance in developing countries: evidence from Ghana. Manag. Audit. J. 22, 319-334.

Wang, Z., Chen, M., Chin, C.L., Zheng, Q., 2017. Managerial ability, political connections, and fraudulent financial reporting in China. J. Account. Public Policy 36, $141-162$.

Weisback, M.S., 1988. Outside directors and CEO turnover. J. Financ. Econ. 20, 431-460.

White, G.O., Boddewyn, J.J., Galang, R.M.N., 2015. Legal system contingencies as determinants of political tie intensity by wholly owned foreign subsidiaries: insights from the Philippines. J. World Bus. 50, 342-356.

Wiklund, J., Shepherd, D., 2005. Entrepreneurial orientation and small business performance: a configurational approach. J. Bus. Ventur. 20, 71-91.

Winkler, J.D., Kanouse, D.E., Ware, J.E., 1982. Controlling for acquiescence response set in scale development. J. Appl. Psychol. 67, 555-561.

Witko, C., 2011. Campaign contributions, access, and government contracting. J. Public Adm. Res. Theory 21, $761-778$.

Wright, M., Filatotchev, I., Hoskisson, R.E., Peng, M.W., 2005. Strategy research in emerging economies: challenging the conventional wisdom. J. Manag. Stud. 42, 1-33.

Xin, K.K., Pearce, J.L., 1996. Guanxi: connections as substitutes for formal institutional support. Acad. Manag. J. 39, 1641-1658.

Yeh, Y., Shu, P., Chiu, S., 2013. Political connections, corporate governance and preferential bank loans. Pac. Basin Finance J. 21, 1079-1101.

Young, M.N., Peng, M.W., Ahlstrom, D., Bruton, G.D., Jiang, Y., 2008. Corporate governance in emerging economies: a review of the principal-principal perspective. J. Manag. Stud. 45, 196-220.

Yu, F., Yu, X., 2011. Corporate lobbying and fraud detection. J. Financ. Quantitative Analysis 46, $1865-1891$. 